\title{
Генноинженерная биотехнология
}

удК 577.214 .622

С. Б. Золотухин, Е. Ю. Маркелова, Г. В. Панасенко, В. Г. Найденов, А. Д. Швед, Ю. Ю. Саутин, Я. В. Пацко

\section{МЕТОД БЫСТРОГО КЛОНИРОВАНИЯ СПЕЦИФИЧЕСКИХ КДНК. КЛОНИРОВАНИЕ КДНК ПРОЛАКТИНА ЧЕЛОВЕКА *}

Oписан метод быстрого и эффективного клонирования определенных кДНК. Метод, включающий цепную реакиио полимеризации с использованием синтетических олигояиклеотидов-затравок, применен длл селективной алплификатии кДНК иролактина, синтезированной на поли(A)-лРНК из аипофиза иеловека. Определение нуклеотидной "ислидовательности вставки одной "з рекомбинантньх плазмид показало налиние полной последовательности кДНК пролактина, флаккированной синтетическими затравKit.utt.

Введение. Традиционный способ клогирования кДНК заданной специфичности заключается в конструировании представительной библиотекн рекомбинантных клонов, содержащих кДНК, синтезированную на поли (А)-содержащей мРНК (поли (A)-мРНК) (рис. 1, a). Скрининг такой библиотеки, количество клонов в которой достигает $5 \cdot 10^{5}$, проводится синтетическими олигонуклеотидами либо зондами, обладающими частичной гомологией с искомыми последовательностями. Этот этап является одним из нанболее трудоемких и часто приводит к обнаружению неполных кДНК-копий и необходимости проведения повторных сқринингов или даже конструирования новых библиотек.

Ранее некоторыми исследователями было проведено обогащение специфическими последовательностями препаратов кДНК на этапах синтсза первой и второй цепей [1]. Такой подход, однако, приводил лишь к частичному обогащению, причем это достигалось за счет потери количества материала. Отличительной чертой данной работы является применение метода цепной реакции полимеризации (ЦРП) [2] для амллификации специфической кДНК, находящейся в гетерогенной популяции других последовательностей с последующим клонированием ее в составе бактериальной плазмиды (рис. 1,6$)$.

Материалы и методы. Синтез олигодезоксирибонуклеотидов. Олиronуклеотиды синтезнровали фосфоамидитным методом [3] на синтезаторе Gene Assembler («Pharmacia», Швеция). После удаления защитных групп обработкой тиофенолом и аммиаком олигонуклеотиды хроматографировали па колонке с Tоуореаг! HW-40. Далее олигонуклеотиды отделяли от полимеров с меньшим числом звеньев с помощью преларативного электрофореза в $15 \%$-ном полиакриламидном геле в присутствин $7 M$ мочевины. Элюированный материал осаждали тремя объемами этанола в присутствии $0,5 \mathrm{M}$ ацетата аммония.

Выделение поли (А)-мРНК из аденомы гипофиза человека. Ткань олеративно удаляемой аденомы замораживали в жидком азоте и хранили при $-70^{\circ} \mathrm{C}$. Пгепарат суммарной и поли (A)-мPHК выделяли, как описано ранее [4, 5]. мРНК проверяли на наличие пролактин-специфических последовательностей методом гель-электрофореза и блоттинга с последующей гибридизацией с ${ }^{32}$ р-меченным 24-звениым олигонуклеотидом-затравкой [6].

* Работа финансировалась в рамках Временного молодежного творческого коллектива. 
С и тез кДНК. кДНК и двухспиральную кДЮК (дс кДНК) синтезировати пю методу Гублера [7]

Ц Р ГІ. 100 нг дс кДНК амплифимировапи в системе 50 мк.т, содержапей 30 м. трис-ацетатный буфер, $\mathrm{pH} 8,60 \mathrm{mM}$ Na-ацетат, $10 \mathrm{mM}$ Mg-ацетат, 1,5 мM dNTPs, 1 мкМ олигонуклеотиды-затравки, 200 ед.'мл ДНК-лолимеразы Thermus thermophilus $H B$ (НПО «Фсрмент», Вильнюс). Проводили 25 циклов: $95^{\circ} \mathrm{C}, 1,5$ мин; $45^{\circ} \mathrm{C}, 2$ мчг;

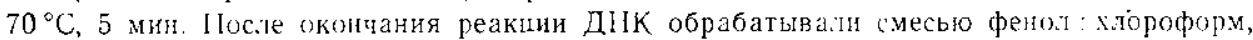

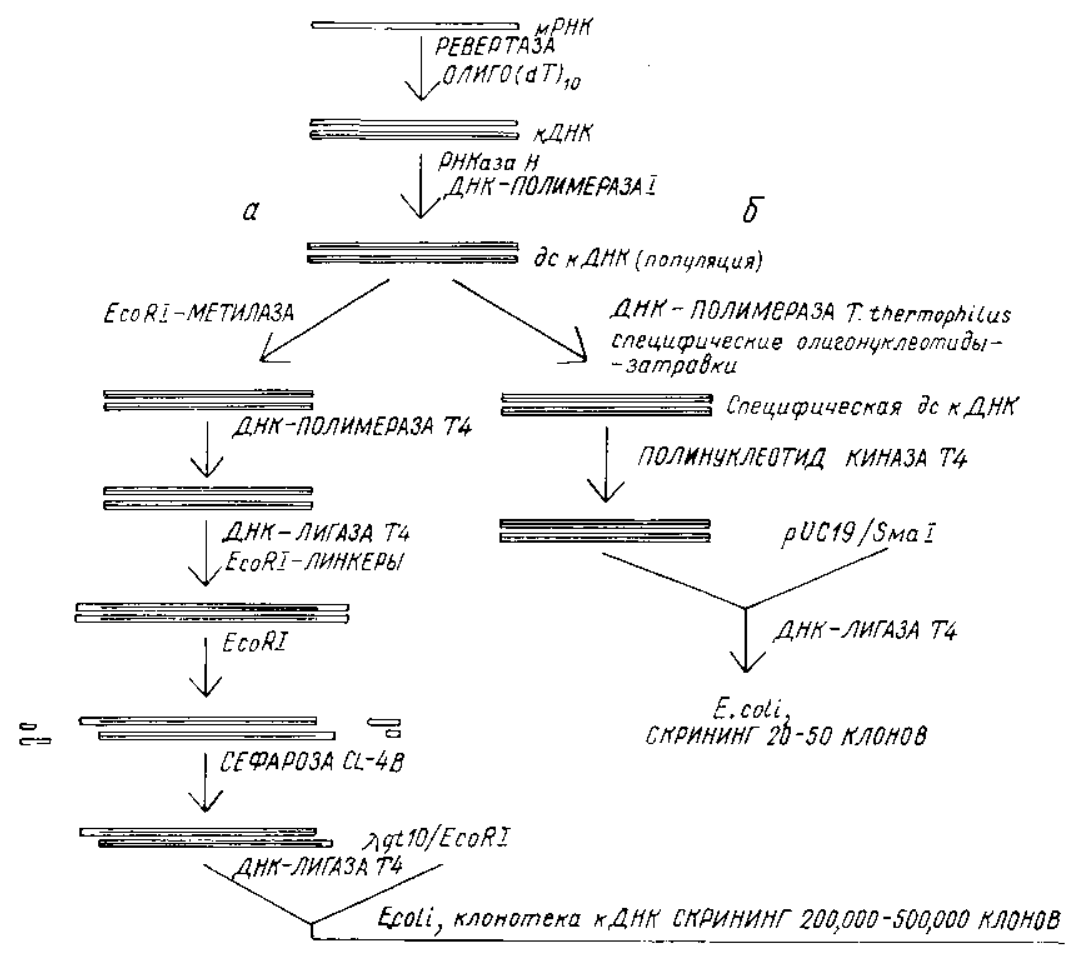

Рис. 1. Традиционная (a) и предлагаемая (6) схемы клонирования специфическнх кДНК

Fig. 1. Traditional $(a)$ and suggested $(\sigma)$ schemes for the synthesis and cloning of specific cDNAs

затем - хлороформом и осаждали этанолом в присутствии $2 M$ ацетата аммония. Растворенную ДНК подвергали электрофорєзу в 0,8\%-ном геле легкоплавкої агарозы («Bio-Rad», CША). ДНК из геля элюировали, как описано ранее [6].

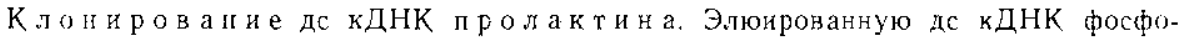
рилировали (5'-концы, образованыые синтетическими олигонук.теотидами) с помощью полинуклеотидкиназы $T 4$ и клонировали в $S m a /$-сайт плазмиды pUC19, используя описанные методы [6]. Рекомбинантные клоны отбирали на селективных средах, содержащих X-ga! и ИПТГ.

Определение иуклеотидиой последовательностиклониров ан н ой кДНК. Нуклеотидню последовательность кДНК пролактина определяли ио методу Сэнгера [8], используя непосредственно рекомбинантную плазмиду pHPr19 в качестве матрицы, универсальные затравки для прямого (17-звенный олигонуклеотид) и обратного сиквенсов (16-звенный олигонуклеотид), а также пролактин-специфическис олигонуклеотиды (16- и 24- и 43-звенные элигонуксеотиды). ДНК плазмиды $p H \operatorname{Pr} / 9$ денатурировали, как описано в работе [9], синтез проводили фрагментом Кленова ДНК-полимеразы I («Amersham», США).

Результаты и обсуждение. Целью данной работы являлось клонирование кДНК, кодирующей пролактин человека. Длина соответствующей поли (A)-мРНК, выделенной из ткани оперативно удаляемой аденомы гилофиза, составляет примерно 1000 н. п. (данные не приведены). Структурная часть этой мРНК начинается с нуклеотидной 
последовательности, кодируюшей сигнальный пептид длиной 28 аминокислот [10]. Отцепление этого пелтида от препролактина происходит на стадии процессинга и транспорта белка, в результате чего из клетки выходит зрелый, физиологически активный гормон.

Синтезированная по традиционной схеме кДНК содержала бы информацию, кодирующую сигнальный пелтид препролактина. Такую кДІІК невозможно было бы использовать в бактериальных клетках для
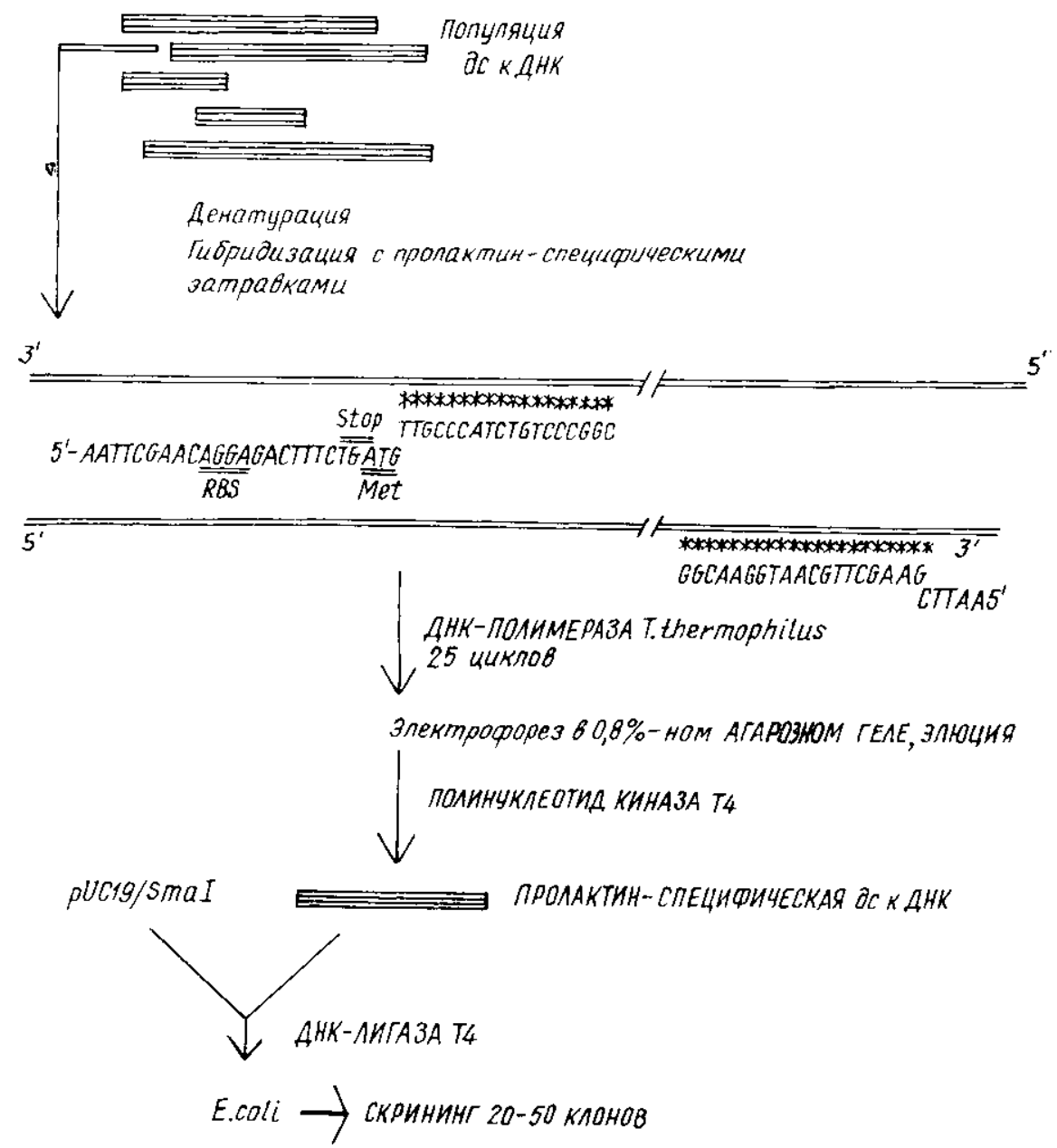

Рис. 2. Схема амп.тификации и клонирования кДНК пролактина человека

Fig. 2. Schematic drawing of amplification and cloning of 1uman pro'actin cDNA

синтеза белка, поскольку у бактерий нет соответствующей системы процессинга. Поставленная цель клонирования кДІК пролактина человека достигалась с помощью ЦРГІ для амплификации данной последовательности, находящейся в гетерогенной популяции кДНК. Для этого использовали два пролактин-специфических олигонуклеотида-затравки (рис. 2). 5'-Концевая затравка (43-звенный олигонуклеотид) содержит в своем составе 18 нуклеотидов, идентичных мРНК, начиная с кодона TTG, кодирующего Leu - первую аминокислоту процессированного гормона. Остальные 25 нуклеотидов содержат участок связывания с рибосомной PHK E. coli (RBS) и перекрывающиеся кодоны TGA (Stop) и ATG (Met), кодирующие терминирующий и инициирующий кодоны соответственно [11].

$3^{\prime}$-Концевая затравка (24-звенный олигонуклеотид) частично комплементарна мРНК в еe $3^{\prime}$-лекодирующей области. Схема экслеримента представлена на рис. 2. Синтезированную на поли (А)-мРНК из 
деномы гипофнза дс кДНК денатурировали, гибридизовали с опианными выше олигонуклеотидами и проводили синтез комплементарых цепей с помощью ДНК-полимеразы T. thermophilus. Амплифициюванную кДНК подвергали электрофорезу в 0,8\%-ном агарозном геле рис. 3). После элюции соответствующей зоны в области 700 н. п.

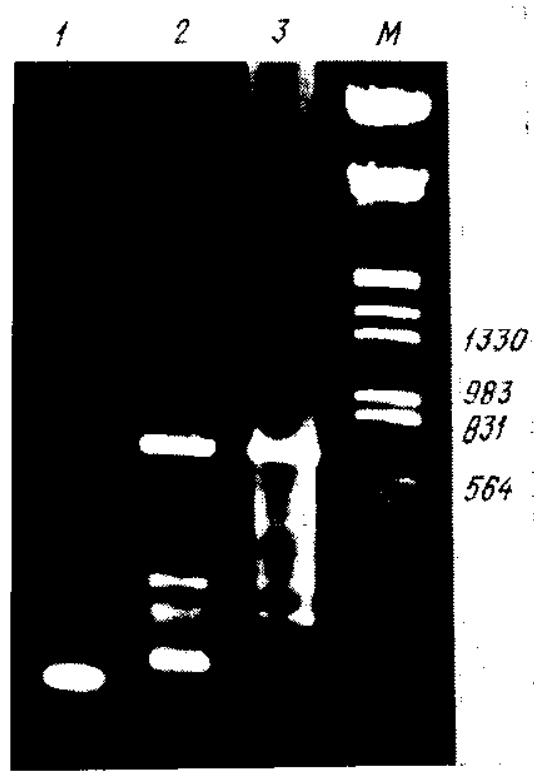

$5^{\prime}$-концы дс кДНК пролактина фосфорилировали и использовали непосредственно для клонирования в Smal-сайт плазмиды $p U C 19$. Скрининг нескольких десятков клонов, выросших на соответствующих индикаторных средах, позволил обнаружить клоны, содержащие кДНК пролактина. Одна из рекомбинантных плазмид, названная $p H \operatorname{Pr} 19$, представлена на рис. 4.

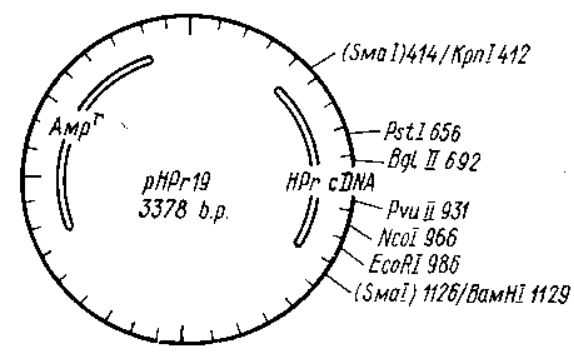

эис. 3. Электрофорез в $0,8 \%$-ном агарозном геле ДНК, синтезированной в цепной реэкции полимеризации: 1-отрицательный когтроль реакции ЦРП (без фермента); ?- амплифицированная кЦНК пролактина человека (препарат 1): 3 - то же (препазат 2); $M$ - маркеры молеку:เяной массы, размеры обозначены в н. п.

ig. 3. $0.8 \%$-A garose ge: analysis of DNA synthesized in polymerase chain reaction: $1-$ regative reaction control (blank); 2 - amplified human prolactin cDNA (sample 1); 3-the same (sample 2); $M$ - molecular weight markers (in. b. p.)

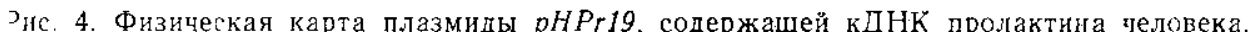
ббозначены сайты узнавания нескольких рестриктаз в последовательности кДНК прогактина и их потожения относительно всей плазмиды (в н. п.). Инактивирование зстраиванием сайгта Smal обозначено скобками

ig. 4. Physical map of the recombinant plasmid pHPr19 containing human prolactin DNA. The recognition sites of some restrictases in the prolactin sequence (in b. p.) re indicated with respect to the total plasmid length. Insertional inactivation of Smalite is indicated by brackets

Нуклеотидная последовательность кДНК пролактина определена непосредственно в составе плазмиды pHPr19. Для этой цели были истользованы три пролактин-специфические затравки и две затравки, трилегающие $\mathrm{k}$ полилинкерной области рUC19. Нуклеотидные послеповательности кДНК пролактина человека, определенная нами и опублнкованные ранее, представлены на рис. 5. Единственное обнаруженное чами отличие - точечная инсерция Т в положении 639 некодируюшей бласти, что, по-видимому, является отражением аллельного полиморфизма гена пролактина человека и не является следствием использоваІия ЦРП для клонирования.

Примененный нами метод клонирования специфических последозательностей кДНК является экономичным, быстрым и позволяет, изכегая стадии конструирования и скрининга представительных библиогек кДНК, получить клон требуемой специфичности, имея в распоряжении не больше 1 мкг поли $(A)$-РНК. Опубликованный недавно метод клонирования кДНК, синтезированной на суммарной клеточной РНК [14] с последующей амплификацией специфической последовательносги по описанному выше методу, позволит существенно упростить технику клонирования. Кроме того, этот подход позволяет клонировать 
полноразмерные копии кДНК, так как размеры определяются самим экслериментатором с помощью синтетических олигонуклеотидов-затравок. Метод, по-видимому, универсален и позволяет клонировать как кДІК с уже известной последовательностью, так и рансе не клонированные кДНК. В таком случае структура 5'-концевого олигонуклеотида

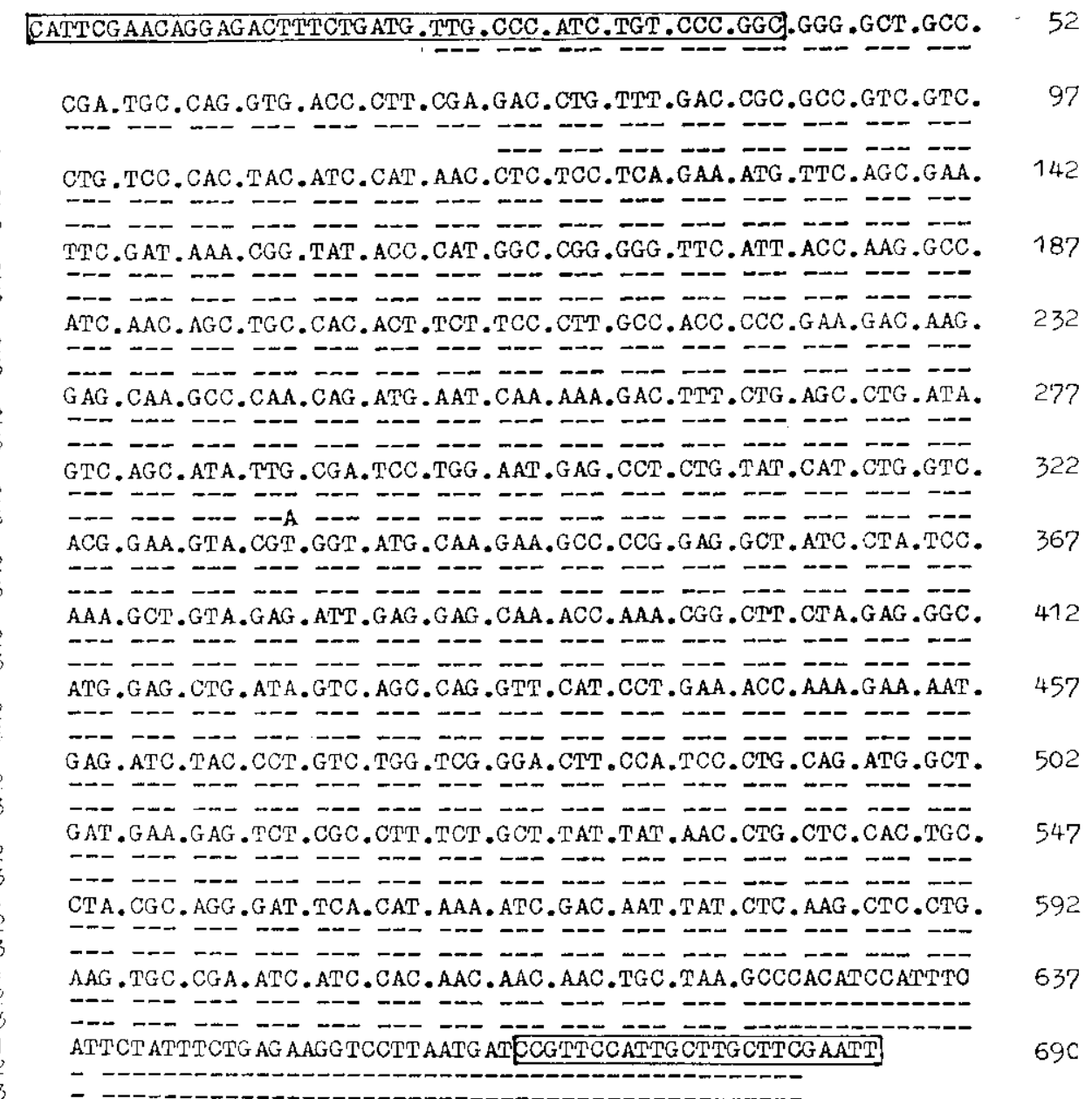

Рис. 5. Нуклеотидная последовательность кДНК пролактина человека, определенная нами (1), в работах [12] (2) и [13] (3). В случаях 2 и 3 указаны только отличия в иуклеотидных последовательностях. Использованные для ЦРП олигонуклеотиды заключены в прямоугольники

Fig. 5. The mucleotide sequence of the cloned human prolactin cDNA (I) in comparison with that of Cooke et al -2 (12) and that of Mertvetsov et al -3 (13). The synthetic oligonucleotides-primers used for PCR are boxed

определяется па основании частичной аминокислотной последовательности пяти - шести N-концевых остатков исследуемого белка (с учетом вырожденности кода и частоты встречаемости кодонов). Этот олигонуклеотид обеспечивает специфичность реакции ЦРП. Структура 3'-концевого олигонуклеотида может быть универсальна: олиго (dT) $12-15$ GGTCGACC, где (dT) $12-15$ обеспечивает гибризидацию с поли (A)-последовательностю на $3^{\prime}$-конце мРНK, а GGTCGACC фиксирует $3^{\prime}$ конец кДНК прн ее амплификации и содержит удобный для клонирования сайт $S a l G I$, редко встречаюшийся в геноме эукариот.

В период подготовки данной статьи были опубликованы еще две работы, подтверждающие универсальность предлагаемого подхода $[15,16]$. 


\section{A FAST METHOD FOR CLONING OF SPECIFIC CDNA. CLONING OF IIUMAN PROLACTIN CDNA}

S. B. Zolotukhin, E. Yu. Markelova, G. V. Panasenko,

V. G. Naidenov, A. D. Shved, Yu. Yu. Sautin, Ya. V. Patsko

Institute of Molecular Biology and Genetics,

Academy of Sciences of the USSR, Kiev

Institute of Endocrinology and Metabolism,

Ministry of Public Health of the Ukrainian S:SR, Kiev;

Institule of Neurosurgery;

Ministry of Public. Health of the Ukrainian SSR, Kiev

Sum ary

A method allowing fast and effective cloning of particular cDNA is described. Pairs of synthetic oligonucleotides-priners are used for polynerize chain reaction mediated selective amplification of prolactine cDNA synthesized on human pituitary poly (A) mRiNA. Sequence of one of the recombinant plasmid insert revealed a full-length prolactin cDNA, flanked by the synthetic primers.

\section{СПИСОК ЛИТЕРАТУРЫ}

1. Schmid A., Catlaneo K., Billeter M. A. A procedure for se'ective full length cDNA cloning of specific RNA sequences// Nucl. Acids Res.-1987.-16, \10-P. 39873996

2. Primer directed enzymatic amplification of DNA with a thermostable DNA polymerase / R. K. Saiki, D. H. Gelfand, S. Stoffel et al.// Science-1988, -241, N 4864-$4865-$ P. $487-491$.

3. Atkinson T., Smith M. Solid phase synthesis of oligo-deoxyribonucleotides by phosphate-triester method//Oligonucieotide synthesis. A practical approach / Ed. M. J. Gait.- New York: IRL press, 1984- - P. 35-82.

4. Comcrunsky P., Sacchi N. Single-step method of R:NA iso!ated by acid guaridinium thiocyanate-phenol-chlorophorm extraction// Anal. Biochem.-1987._162, \2P. $1106-59$.

5. Aviv H., Leder P. Purification of biologicaliy active globia messenger RNA by chromatography on oligothymidylic acid-cellulose: Proc. Nat. Acad. Sci. USA._1972.... 69, N 6.- P. $11408-1412$

6. Маниатис Т., Фрић Э., Сәмбрук Дж. Молекулярное көтонирование.-М. : Мир, $1984-479$

7. Gubler U., Hoffman B. J. A simple and very efficient method for generating cDNA libraries // Gene.-1983.-25, \> 2-3.-P. 263-269:

8. Sanger F., Nicklen S., Coulson A. R. DNA sequencing with chain-terminator inhibitors / Proc. Nat. Acad. Sci. USiA - 1977-74, N 12. - P. 5463-5467.

9. Double stranded DNA sequencing as a choice for DNA sequencing/H. Zhang, R. Scholl, J. Browse, C. Somerville // Nucl. Acids Res. -1988,-16, N 3-P. 1220.

10. Evann G. A., Huncko J., Rosenfeld $M$. G. Preprolactin represents the initial product of prolactin in mRNA translation // Endocrinology.-1977.-101, N 3.-P. 1807-1. 814 .

11. Создание «искусственных гибридных оперонов с частично перекрываюшимися генами» для достижения экспрессии гетерологических генов в клетках Escherichia coli / С. М. Мапко, А. Л. Лапидус, М. Э. Трухан и др. // Молекуляр. биология. $1987 .-$ 21 , io 5.-C. $1297 \ldots 1310$

12. Human pro'actin. cDNA structural analysis and evolutionary comparisons / N. E. Cooke, D. Coit, J. Nhine et al. //J. Biol. 'Chem, - 1981.-256, N 8-P. 4007-4014.

13. Синтез, клонирование и определение первичной структуры ДНК, комплементарной мРІІҚ пролактина из гипофиза человека /Н. П. Мертвецов, С. Я. Головин, 'С $\bar{M} .3 \mathrm{e}$ ленин и др. // Биоорг. химия.—1987. - 13, № 12, ‥ С. 1687-1690.

14. Lu X., Werner $D$. Construction and quality of $C D N A$ libraries prepared from cyteplasmic RNA not enriched in poly $(A) \div+\mathrm{R}$ NA / / Gene- $1988-71, \mathrm{~N} 1,-\mathrm{P}$. $157-$ 164.

15. Белявский $A$. B., Расвский $K$. Амплификация тотальной кДНК in vitro//Докп. AH CCCP...- 1988 - 303, № 6-C. 14918-1501.

16. Frohman M. A., Dush M. K., Martin G. R. Rapid production of full-length cDNAs from rare transcripts: amplification using a single gene-specific oligonucleotide primer// Proc. Nat. Acad. Sci. US A.-19.88.-85, N 23.-P. 8998-91002.

ИІІ-т молекуляр. биологии и генетики

Получело 05.05 .89

AH УССР. Киев

Ин-т эндокринологин и обмена веществ ІМЗ УССР, Қиев

Ин-т нейрохирургии МЗ УССР, Киев 